\title{
THE ROLE OF OCCUPATIONAL CONCERNS ON THE REALITY SHOCK EXPECTATION
}

\author{
Murat ÖZDEMIR, Hilal BÜYÜKGÖZE \\ Hacettepe University, Hacettepe Universitesi Beytepe Campusu Egitim Fakultesi \\ Egitim Bilimleri Bolumu Cankaya, 06800 Ankara, Turkey \\ E-mail: hilal.buyukgoze@gmail.com
}

\begin{abstract}
Reality shock is experienced mostly by novice teachers in transitioning to profession when they are confronted with a gap between what they learned during their education and the reality awaiting them within the early years of their career. Similarly, senior students in teaching programs may have occupational concerns proceeding from not having encountered the profession itself yet. Here, we elaborate on the relationship between reality shock expectation and occupational concerns of pre-service teachers. A total of 464 Turkish pre-service teachers participated. We discovered experiencing reality shock expectation prior to professional life to be significantly predicted by appointment, students/communication, and social/economic concerns. Moreover, there was a significant interaction between study major and reality shock expectation of the participants. Overall, we discuss the probable factors triggering reality shock expectation and occupational concerns, and the implications for future research in accordance with similar literature.
\end{abstract}

Key words: reality shock expectation, occupational concern, pre-service teacher, Turkey

Though initial teacher training policies differ among countries, the challenges that preservice teachers face in the process of transition to teaching profession are similar. Studies conducted in several countries revealed that pre-service teachers transitioning into the profession commonly experience problems with school principals and inspectors, have heavy workloads, feel incompetent in classroom management, and have social status problems (Korkmaz, Saban, \& Akbaşl1, 2004; Öztürk \& Yıldırım, 2013; Senom, Zakaria, \& Shah, 2013; Veenman, 1984). Furthermore, research in several countries also found that the participants experience occupational concerns, perception of incompetence, and reality shock in the early years of their career (Beck, 1993; Dyess \& Sherman, 2009).
One of the reasons that teachers in transition to profession experience these kinds of problems may be attributed to insufficient initial teacher education (Farrell, 2006). Previous studies paradoxically implied that preservice teachers have a high sense of teaching self-efficacy (Al-Awidi \& Alghazo, 2012; Külekçi, 2011). However, pre-service teachers' self-efficacy level tends to decrease after entering the profession (Pendergast, Garvis, \& Keogh, 2011). Weinstein (1988) analyzes the situation based upon the conceptualization of 'unrealistic optimism,' and claims that optimistic expectation is largely superseded by a 'reality shock' during the transition from pre-service education to actual teaching experience.

The main reason described by teachers as to why they leave the profession is arising

DOI: $10.21909 / \mathrm{sp} .2016 .03 .717$ 
from the reality shock that they experience in the early years of teaching (Ingersoll \& Smith, 2004). Further, it is also demonstrated that the reality shock that novice teachers experience results in diminishing levels of professional commitment (Dean \& Wanous, 1983; Dean, Ferris, \& Konstants, 1988). Recent studies conducted in numerous countries have revealed that the proportion of teachers who leave the profession as a result of having experienced reality shock has reached an outrageous level (Goddard \& Goddard, 2006; Mafora, 2013; Trent, 2012). For instance, it was reported that $25 \%$ of the teachers in Australia resign in the early years of their teaching career (Department of Education, Science and Training, 2003). In developed Western countries, $25 \%$ to $40 \%$ of newly recruited teachers resign due to suffering from job burnout (Darling-Hammond, 2000; Ewing \& Smith, 2003; Macdonald, 1999). A considerable number of schools, particularly in rural areas facing a shortage of teachers on account of this downward tendency, have been examined (Harmon, 2001). Results of such studies showed that this situation ultimately and primarily influences the students in these schools, as the most efficacious human resource for their academic development is their teachers (Rowan, Correnti, \& Miller, 2002; Wright, Horn, \& Sanders, 1997).

The upward trends in the number of teachers feeling less committed toward their profession, experiencing burnout, or even leaving the profession due to reality shock threaten the sustainability of the educational services on local, regional, and global scales. Addressing these matters, a substantial number of research were conducted on the multidirectional problems caused by reality shock over the past several decades (e.g., Betts,
2006; Caires, Almeida, \& Martins, 2010; Chubbuck, 2008; Haggarty \& Postlethwaite, 2009; Hagger, Mutton, \& Burn, 2011; Hobson \& Ashby, 2012; Horn, 1966). In recent years, studies on reality shock have increasingly been focused on pre-service teachers (Chong, Low, \& Goh, 2011; Gibbs, 2002). In one of these studies, pre-service teachers' reality shock expectation was investigated in terms of the relationship between their motivation and sense of teaching efficacy (Kim \& Cho, 2014).

It has been realized that there is a gap in the literature between studies concerning pre-service teachers' reality shock expectation, and their occupational concerns associated with it. Therefore, the aim of the present research is to empirically examine the relationship between occupational concerns and reality shock expectation, of which negative impacts on pre-service teachers are felt on a universal scale. In addition, in the current study, we intended to explore whether the participants' opinions differed significantly in relation to gender, teacher education program, accommodation unit, and socioeconomic status when their occupational concern levels were controlled statistically, and whether their occupational concern level was a significant predictor of their reality shock expectation.

\section{Conceptual Framework and the Context of the Research on Reality Shock Expectation}

In the process of transition to the teaching profession, some novice teachers have been found to leave the profession, become less committed to the profession, or experience professional burnout owing to various challenges they may have been confronted 
with. A significant reason for this is stated to be arising from "reality shock," defined as "a clash between pre-service teachers' ideal expectations of teaching settings formed during the period of teacher training and the reality of everyday classroom life" (Veenman, 1984). Kramer (1974) defines reality shock in a manner similar to the reaction that new workers produce as they construe that their current work situation is different from the one for which they have prepared themselves during the years of their training (cited in Stacey \& Hardy, 2011, p. 159). In other words, reality shock is posited to be the replacement of unrealistic optimism felt in the early years of the profession with cynicism (Rousseau, 1968).

One of the main reasons prompting reality shock is that pre-service teachers are not prepared enough for the diverse roles and responsibilities they will inevitably encounter in schools (Richards, Templin, \& Gaudreault, 2013). In studies conducted on novice teachers, it was discovered that teachers who experienced reality shock had been subject to various difficulties and troubles leading to the loss of their self-confidence as a teacher. For instance, a study revealed that teachers have problems related to "security" and "support" in the early years of the profession. In the aforementioned study, participants drew attention to the significance of initial teacher education in dealing with the same or similar and probable problems (Chubbuck, Clift, Allard, \& Quinlan, 2001).

The reality shock experienced by newcomers may lead to a number of positive and negative results concerning both the employee and the organization. In prior research, for example, it was observed that organizational commitment levels tend to decrease by employees who experienced reality shock (Dean \& Wanous, 1983; Dean, Ferris, \& Konstants, 1988). Another study showed that employees who experienced reality shock have intentions of leaving the profession (Dhar, 2012). Nevertheless, yet another study stated that reality shock triggers newcomers to improve themselves substantially (Depolo, Fraccaroli, \& Sarchielli, 1992). Duchscher (2009), based on the findings of his study, dwells on the importance of getting pre-service teachers ready for the upcoming difficulties throughout their initial teacher education in order to minimize the negative impacts of reality shock experienced in the process of their professional transition.

The current study investigated the reality shock expectations of pre-service teachers rather than the novice teachers' expectation of reality shock. Therefore, a suitable, operational definition of the "reality shock expectation" is required for the present study. In this study, the reality shock expectation is conceptualized as "pre-service teachers' expectation of reality shock during the first year of their professional teaching as the anticipation of a gap between what they have learned in the teacher education program and the reality that awaits them within the first year of teaching, with respect to the work of teaching and the context in which teaching will occur" (Kim \& Cho, 2014, p. 68).

\section{Occupational Concerns}

Among the factors that give pre-service teachers reality shock expectation, might be the concerns they have toward the teaching profession itself. These concerns are defined as "the subjectively unpleasant feelings of dread over something unlikely to happen, such as the feeling of imminent death" 
(Davison, 2008, p. 154). Accordingly, occupational concern can be defined as the disturbing fear felt by pre-service teachers in their inner world, who have not yet encountered the profession itself, explained by not knowing what they will be confronted with. According to Fuller (1969) who has a largely recognized self-developed model in teacher development literature, pre-service teachers have three consecutive types of occupational concerns, namely 'concerns about self', 'concerns about task' and 'concerns about students and the impact of teaching'. A preservice teacher feeling concerns about self, ponders on whether he/she will perform in the profession successfully. Regarding the concerns about task type, the pre-service teacher may have concerns about being an efficient educator in the future. Finally, a preservice teacher who has concerns about students and the impact of teaching worries about contributing to the students' education overall.

Prior studies were documented that novice teachers have more occupational concerns compared to experienced teachers (Alasheev \& Bykov, 2002; Wagner, 2008). Pre-service teachers are reported to have occupational concerns about communication with students, getting employed, everyday school life, professional penetration, and the environment (Cabı \& Yalçınalp, 2009; Sammephet \& Wanphet, 2013). Another study also explained that pre-service teachers were concerned about classroom management and how the inspectors and the students would assess them as teachers (Fuller, 1975, p. 176). When an overall assessment is made, taking into account the findings referred to formerly, it is postulated that preservice teachers have concerns about tasks, responsibilities, and roles pertaining to the profession of teaching. Thus, in the present study it is assumed that the upward tendency of occupational concerns can predict the reality shock expectation.

\section{Initial Teacher Education in Turkey and Occupational Concerns of Teachers}

Focusing on the relationship between the reality shock expectation and occupational concerns of pre-service teachers, this study was conducted in Turkish universities. Initial teacher education in Turkey is under the responsibility of the education faculties affiliated with universities. The foundation of teacher education system is based on the Project of Developing National Education (PDNE), which took effect after the signing of the World Bank and the Republic of Turkey(Kavcar, 2002). The selection and admission of students to education faculties are administered by the public institution, the Student Selection and Placement Center. Preservice teachers who gain the right to receive education in the education faculties also gain the qualifications of a teacher after four years of training, and graduate with the title of "teacher" (Yeşil, 2009).

To become appointed to teaching posts in public schools, newly graduated teachers are required to take and pass the nationwide exam called the Civil Servant Selection Examination (abbreviated as KPSS in Turkey), regularly held every year. The KPSS intends to measure general competencies and the extent of pedagogical content knowledge of pre-service teachers. Being successful on the KPSS is compulsory, yet it is not enough to get appointed to public schools. The Ministry of National Education (MEB), the authority for all educational services in Turkey, annually publicizes open teaching posts by 
subject, and then appoints the required number of teachers. The MEB divides Turkey into three service regions according to the level of economic and social development. New entrants are appointed to the least socially and economically developed public schools in the service region of the country. These schools are located in less developed accommodation units where population is sparse and scattered. A new entrant appointed to one of these schools must stay there for at least three years, if he/she does not have any valid health or spouse-related excuses (MEB, 2010).

As it is portrayed so far, the education, selection, and recruitment processes of preservice teachers in Turkey have a considerable number of difficulties. It is probable that these difficulties increase the level of occupational concern of pre-service teachers, and this triggers the expectation of reality shock for them. To our knowledge, there has been a number of researches in line with these findings in related literature from Turkey. A study, for instance, reported that pre-service teachers who must succeed in KPSS to get appointed to a public school have concerns about it (Ekici \& Kurt, 2012). Another study revealed that the expectations of the majority of pre-service teachers toward the teaching profession, who are studying in teacher education programs of education faculties, cannot be met at the desired level, and they have higher levels of occupational concerns (Karamustafaoğlu \& Özmen, 2004).

Quantitative research on whether various socio-demographic variables matter in occupational concerns that pre-service teachers experience in Turkey had also been conducted. For example, a study focusing on whether gender matters in occupational concerns showed that female pre-service teach- ers have a higher level of occupational concern than male pre-service teachers (Dursun $\&$ Karagün, 2012). Further, teachers become relatively more occupationally concerned as they get older as implied in a study based on the impact of age (Atmaca, 2013). Research on the relevance of the class/year of college showed that seniors are more occupationally concerned than freshman and sophomore students (Saban, Korkmaz, \& Akbaşl1, 2004; Ünaldı \& Alaz, 2008). Studies conducted on various teacher education program students were indicated that pre-service teachers' occupational concern levels were associated with their programs as well (e.g., Çubukçu \& Dönmez, 2011; Korkmaz, Saban, \& Akbaşl1, 2004; Saracaloğlu, Kumral, \& Kanmaz, 2009). It has been also figured out that the accommodation unit where preservice teachers spent most of their lives was examined in several studies as an independent variable (e.g., Bozdam \& Taşğın, 2011; Kiraz, Demir, Aksu, Daloğlu, \& Yıldırım, 2010). In such studies, the authors questioned whether having lived in big cities, towns or villages mostly had any influences on preservice teachers' concern levels, and diverse results were found to be reported in related literature. Socio-economic status of pre-service teachers was examined in relation to its association with occupational concern likewise. For instance, a study showed that preservice teachers' occupational concern levels did not vary in relation to their socioeconomic status (Ekici \& Kurt, 2012), whereas Adıgüzelli (2015) reported that pre-service teachers with low socio-economic status have higher levels of occupational concern than the ones with high socio-economic status. When an overall assessment was made considering these findings, it is better understood that pre-service teachers in Tur- 
key have concerns about the teaching profession, and these concerns differ according to socio-demographic variables. These findings also give rise to thoughts that preservice teachers' reality shock expectation levels may differ based on various sociodemographic variables. Accordingly, in the current study it was intended to elaborate on the following research questions:

- What are the participants' overall reality shock expectation and occupational concern levels?

- Are there any correlations between reality shock expectation and occupational concern?

- Is gender, teacher education program, accommodation unit and socio-economic status associated with reality shock expectation?

- Is occupational concern level of university students a significant predictor of their reality shock expectation level?

\section{Method}

\section{Participants}

Participants were a total of 464 pre-service teachers ( $70.9 \%$ women; $29.1 \%$ men) attending $4^{\text {th }}$ year in their full-time teacher education programs at two different state universities in Ankara and Samsun in Turkey. The teacher education programs of the participants included elementary education (30.8\%), foreign language education (15.9\%), psychological guidance and counseling (6.5\%), special education $(9.7 \%)$, computer and technology education (17\%), Turkish language education $(9.5 \%)$ and science and math education $(10.6 \%)$ at the time of data collection. The mean age of the participants was 22.55 years $(S D=2.29$, age range $=19-35$ years). Of the participants $74.4 \%$ spent most of their lives in big cities and the rest lived in rural areas including towns $(16.8 \%)$ and villages $(8.8 \%)$ mostly. As for the socio-economic status of the participants, $212(45.7 \%)$ of them were found to spend 500 Turkish Liras (TL, approximately 175 USD) or less in a month's time, $38.8 \%$ mostly spent between $501 \mathrm{TL}$ to $1,000 \mathrm{TL}$ (app. 175 USD to 350 USD) monthly, $8.8 \%$ of them spent from 1001 TL to 1500 TL (app. 350 USD to 525 USD), and the rest of them were found to spend 1,501 TL to 2,000 TL (app. 525 USD to 700 USD) in a month's time.

\section{Instruments}

Reality Shock Expectation Scale (RSES)

Reality shock expectation of the participants was measured using the Reality Shock Expectation Scale (RSES) that was originally developed by Kim and Cho (2014). The RSES is a 9-item, 7-point Likert type scale ranging from (1) totally disagree to (7) totally agree. A sample item of the RSES is 'The reality of teaching methods used in the classroom will be different from what I was taught as a student teacher.' Higher scores posit that participants have higher levels of concern toward the first year of the profession. In the original study, the Cronbach alpha coefficient was calculated to be .88 . In this preliminary study, the one-factor-construct of the Turkish version of the scale was tested by confirmatory factor analysis (CFA). The CFA yielded the following goodness of fit indexes; $\left[\chi^{2}\right.$ (chi-square $)=92.34 ; d f$ (degree of freedom) $=27 ; \chi^{2} / d f=3.42$; AGFI (adjusted goodness of fit index $)=.87$; GFI (goodness of fit index $)=.92 ; \mathrm{NFI}($ normed fit index $)=.89$; CFI (comparative fit index) $=.92$; IFI (incre- 
mental fit index $)=.92 ;$ SRMR $($ standardized root mean square residual $)=.06$; RMSEA (root mean square error of approximation $)=$ .08]. The internal consistency of the scale was reported as .78. Taking these scores into account, the RSES was considered as an adequately valid and reliable data collection tool to measure pre-service teachers' reality shock expectation.

\section{Occupational Concern Scale (OCS)}

Occupational concern level of pre-service teachers was measured using the Occupational Concern Scale-OCS developed by Cab1 and Yalçınalp (2013). The OCS is a 45-item, 5-point Likert type scale with 8 subscales ranging from (1) totally disagree to (5) totally agree. The 'concern about task' subscale consists of 14 items and a sample item is ' $I$ am concerned about catching students' attention in the lesson.' The second subscale of the OCS which is entitled as ' $\mathrm{SO}$ cial and economic concerns' consists of seven items and a sample item for this subscale is ' $I$ am concerned about not being able to participate in social and cultural events by reason of low income.' The 'concern about students and communication' subscale has six items and a sample item of the subscale is as follows: 'I am concerned about not being able to communicate with the students.' An example item from the 5item 'concern about colleagues and parents' subscale is ' $I$ am concerned about not being able to communicate with my colleagues.' The 'concern about personal development' subscale has four items and a sample item is as follows: 'I am concerned about not being able to be a good role model for my students.' The sixth subscale of the OCS, which is entitled as 'concern for appointment', consists of three items and a sample item for this subscale is 'I am concerned about getting low score on the appointment examination.' The 'concern about adaptation' subscale has three items and a sample item of the subscale is as follows: 'I am concerned about feeling regretful of choosing teaching satisfaction.' The last subscale of the OCS, which is entitled as 'concern about school administration', also consists of three items and a sample item for this subscale is 'I am concerned about having trouble with school administration.' The result of exploratory factor analysis of the OCS revealed an eight factor solution. The Cronbach alpha value for the original OCS was calculated to be .95 , The Cronbach alpha values of the subscales in the present study were found to be .93 , $.83, .91, .78, .86, .86, .71$ and .69 sequentially. ACFA was conducted and the model fit indices from the confirmatory factor analysis showed a good fit between the initial model and the observed data; $\chi^{2}=2505 ; d f=903$; $\chi^{2} / d f=2.77$; $\mathrm{AGFI}=.78 ; \mathrm{GFI}=.81 ; \mathrm{NFI}=.94$; $\mathrm{CFI}=.96 ; \mathrm{IFI}=.96 ; \mathrm{SRMR}=.07 ; \mathrm{RMSEA}=$ .06 . The reliability of the OCS was found to be .95 within the current study. Taking these values into account, the OCS was determined as a valid and reliable instrument for the study.

\section{Data Analysis}

The validity values of the data collection tools were performed via confirmatory factor analysis. The CFA calculations were made via LISREL 8.8 version. All other analyses were performed via SPSS 20 version. To assess the normality distribution of the data set, skewness and kurtosis values were calculated. The results showed that data set of the reality shock expectation had a .62 skew- 
ness value and a .55 kurtosis value. The skewness value for occupational concern data set was calculated to be.- .33 , and .29 as kurtosis value. The skewness and kurtosis values were found to be between -1 and +1 . Therefore, it can be interpreted that both data sets suggested a normal distribution. In order to examine the assumption of linearity between the variables, scatterplots were generated. When the scatterplots were checked, it was figured out that the diagrams obtained from the data set were elliptical. Thus, it was concluded that the data met the assumption of linearity. The one-dimensional and multidimensional outliers were examined as well. As for one-dimensional outlier detection, $z$ scores for individuals were calculated, and it became apparent that there were no $z$ scores out of $\pm 3\left(z_{\text {maxRSE }}=2.10, z_{\operatorname{minRE}}=\right.$ $\left.-2.82 ; z_{\operatorname{maxOC}}=3.08, z_{\operatorname{minOC}}=-2.19\right)$. So as to detect multi-dimensional outliers, Mahalanobis distance was measured, and Mahalanobis distance values were found to be between 0.00 and 13.32. As the ratio of chisquare to degree of freedom and the probability value was not higher than 10.827 , which is the critical value for 0.001 , it was evidenced that there were no multi-dimensional outliers in data set. Further, to examine whether multicollinearity existed among the independent variables, mutual correlation coefficients were calculated, and it was determined that there were no multicollinearity issues among the variables $\left(r_{\mathrm{RSE}-\mathrm{OC}}=0.29\right)$. The reliability of the scales was calculated via Cronbach alpha coefficients. In the data analysis process, the mean scores and the standard deviations of the participants' reality shock expectations and occupational concerns were calculated first. Then, the correlation coefficients for the correlations among the variables were examined. When the occupational concern levels of pre-service teachers were controlled to determine whether the reality shock expectation levels of pre-service teachers differed in relation to their gender, teacher education program, accommodation unit, and socio-economic status, it was tested by covariance analysis (ANCOVA). Lastly, a multiple regression analysis was conducted to examine whether pre-service teachers' occupational concern level were a significant predictor of their reality shock expectation.

\section{Results}

A correlation matrix is presented in Table 1 including mean scores of pre-service teachers for the RSES, the OCS and its subscales, standard deviations, and correlation coefficients of the variables.

As seen in Table 1, participants' reality shock expectation is relatively high $(M=5.00$, $S D=.94)$. The participants' occupational concern was found to be moderate. Participants have concern about appointment mostly. Furthermore, as seen in Table 1, there is a low, positive and significant correlation between reality shock expectation and overall occupational concern levels of the participants $(r=.24, p<.001)$. The correlations between reality shock expectation and the subscales of the OCS were found to be low, yet significant. These findings point to a relatively high correlation between reality shock expectation and concern about students/ communication.

A one-way analysis of covariance (ANCOVA) was also conducted within this study. Dependent variable was the pre-service teachers' expectation of reality shock and the covariate was the participants' scores on the occupational concern scale. First, the 
homogeneity of regression, which is an ANCOVA assumption, was calculated for each of the four independent variables separately. The results indicated that the joint impact of occupational concern*gender $F(1,460)=5.87, p<.01$; occupational concern*department $F(6,457)=2.34, p<.01$; occupational concern*accommodation unit $F(2,458)=.20 p<.01$, and occupational concern*sum of monthly expenditure $F(3,456)=1.93, p<.01$ on reality shock expectation of the participants were not statistically significant.
After adjustment by covariate, expectation of reality shock of pre-service teachers did not vary significantly in relation to gender $F(1,461)=3.21, p>.05$; accommodation unit $F(2,460)=1.31, p>.05$; and socio-economic status $F(3,459)=.54, p>.05$. However, after adjustment by covariates, pre-service teachers' expectation of reality shock varied significantly in relation to their teacher education programs $F(6,456)=2.45, p<.05, \eta^{2}=$ .03 (see Table 2). The results of Bonferroni test showed that reality shock expectation of elementary teacher education program stu-

Table 1 Correlations of Reality Shock Expectation and Occupational Concerns

\begin{tabular}{lcccccccccc}
\hline & 1 & 2 & 3 & 4 & 5 & 6 & 7 & 8 & 9 & 10 \\
\hline 1. Reality shock expectation & -- & & & & & & & & & \\
2. Occupational concern & .29 & -- & & & & & & & & \\
3. Concern about task & .23 & .89 & -- & & & & & & & \\
4. Social and economic concern & .23 & .64 & .34 & -- & & & & & & \\
5. Concern about students/communication & .27 & .79 & .28 & .28 & -- & & & & & \\
6. Concern about colleagues/parents & .18 & .80 & .65 & .48 & .53 & -- & & & & \\
7. Concern about personal development & .23 & .76 & .68 & .38 & .60 & .61 & -- & & & \\
8. Concern about appointment & .18 & .35 & .16 & .29 & .19 & .18 & $.10^{*}$ & -- & & \\
9. Concern about adaptation & .15 & .57 & .33 & .60 & .28 & .41 & .28 & .29 & - & \\
10. Concern about school administration & .16 & .65 & .47 & .47 & .38 & .63 & .42 & .20 & .39 & -- \\
& & & & & & & & & & \\
$M$ & 5.00 & 2.62 & 2.43 & 2.90 & 2.65 & 2.21 & 2.42 & 3.56 & 2.71 & 2.76 \\
$S D$ & .94 & .73 & .91 & .95 & 1.07 & .90 & 1.14 & 1.16 & 1.12 & .99 \\
\hline Note. All correlations significant at the $p<.01$ level. ${ }^{*}$ Correlation is significant at the $p<.05$ level. & &
\end{tabular}

Table 2 Analysis of co-variance (ANCOVA) for pre-service teachers' expectation of reality shock by gender, teacher education program, accommodation unit and socioeconomic status

\begin{tabular}{lcccc}
\hline Variables & $d f$ & $F$ & $\eta^{2}$ & $p$ \\
\hline Gender & 1 & 3.21 & .007 & .074 \\
Teacher Education Program & 6 & 2.45 & .031 & $.024^{*}$ \\
Accommodation Unit & 2 & 1.31 & .006 & .270 \\
Socio-economic Status & 3 & 0.54 & .004 & .649 \\
\hline
\end{tabular}

Note. ${ }^{*} p<.05$ 
dents $(M=5.11, S D=.07)$ was higher than special education program students $(M=$ $4.59, S D=.13$ ). There was no statistically significant difference among other teacher education programs of participants.

A multiple-regression analysis was conducted to explore the extent to which subscales of the occupational concern served to significantly predict reality shock expectation. The results are presented in Table 3 below.

Table 3 shows the predictability of subscales of occupational concerns on reality shock expectation. A multiple correlation of .33 was obtained from the analyses. Values of $R^{2}=.11$ and adjusted $R^{2}=.09$ imply that about $11 \%$ of variance is shared by the criterion and the predictor variables, which is also statistically significant $\left[F_{(8-455)}=7,12\right.$, $p<.001]$. Three of the correlation coefficients are statistically significant including social/economic concern $(t=2.500, p<.05)$, concern about students/communication $(t=2.726, p<.05)$, and concern about appointment $(t=2.223, p<.05)$. Beta value indicates that concern about students/communication has a much higher weight $(\beta=$ .20) than social/economic concerns $(\beta=.15)$ and concern about appointment $(\beta=.11)$. However, rest of the regression coefficients are not statistically significant, including concern about task $(t=-.028, p>.005)$, concern about colleagues/parents $(t=-.813$, $p>.005)$, concern about personal development $(t=1.292, p>.005)$, concern about adaptation $(t=-.044, p>.005)$, and concern about school administration $(t=.039$, $p>.005)$.

Table 3 Multiple regression of occupational concerns on pre-service teachers' expectation of reality shock

\begin{tabular}{|c|c|c|c|c|c|}
\hline & $\begin{array}{l}\text { Sources of } \\
\text { Variation }\end{array}$ & $d f$ & $\begin{array}{l}\text { Sum of } \\
\text { Squares }\end{array}$ & $\begin{array}{l}\text { Mean } \\
\text { Squares }\end{array}$ & \\
\hline Multiple R: 0.334 & -- & -- & -- & -- & \\
\hline R Square: 0.111 & Regression & 8 & 46.150 & 5.769 & \\
\hline Adjusted R Square: 0.096 & Residual & 455 & 368.369 & 03810 & \\
\hline Standard Error of Estimate: 0.89978 & Total & 463 & 414.519 & -- & \\
\hline \multicolumn{6}{|l|}{$F, 7.12 ; p<.001$} \\
\hline \multicolumn{6}{|c|}{ Variables in the Equation } \\
\hline Independent Variable & $B$ & $S E B$ & $\beta$ & t-value & $p$ \\
\hline Constant & 3.826 & 0.182 & - & 21.051 & .000 \\
\hline Concern about task & -.002 & .085 & -.002 & -.028 & .978 \\
\hline Social and economic concern & .150 & .060 & .151 & 2.500 & $.013^{*}$ \\
\hline Concern about students/communication & .171 & .063 & .195 & 2.726 & $.007 *$ \\
\hline Concern about colleagues/parents & -.060 & .074 & -.057 & -.813 & .416 \\
\hline Concern about personal development & .069 & .053 & .083 & 1.292 & .197 \\
\hline Concern about appointment & .086 & .038 & .105 & 2.223 & $.027 *$ \\
\hline Concern about adaptation & -.017 & .048 & -.020 & -.044 & .731 \\
\hline Concern about school administration & .002 & .056 & .002 & .039 & .969 \\
\hline
\end{tabular}

Note. ${ }^{*} p<.001$ 


\section{Discussion}

In the present study, the multifaceted relational structure between reality shock expectations and occupational concerns was investigated on the basis of pre-service teachers' opinions. In the study, it was intended to figure out to what extent reality shock is experienced prior to professional life. Accordingly, the aim was to identify the perceptions of pre-service teachers about reality shock observed during the transition years to the teaching profession, and of which negative impacts were experienced on local, regional, and global scales.

Within this framework, the degree to which pre-service teachers experienced expectations of reality shock and occupational concerns was investigated first. Findings indicated that participants' reality shock expectation level was high, and their occupational concern level was relatively low. Therefore, this study is in line with the previous research, which revealed that pre-service teachers felt competent about the issues related to teaching, yet they had concerns about other challenges they would experience in the transition process into the profession (Goddard \& Goddard, 2006; Külekçi, 2011; Mafora, 2013; Trent, 2012). The study also revealed that main concerns of pre-service teachers were about getting appointed, and social and economic concerns. Hence, pre-service teachers were found to lack the knowledge and competencies required to cope with potential challenges in the future. The researchers believe that this is one of the factors accelerating reality shock expectations of pre-service teachers. Thus, the most differential finding of the current study was that the reality shock expectation expe- rienced by teachers in the early years of their professional life (Stokking, Leenders, de Jong, \& van Tartwijk, 2003) in fact began to be experienced during the initial teacher education, depending on this reason and similar other reasons. Another probable factor triggering reality shock expectations of pre-service teachers is insufficient preparation for the potential professional roles and responsibilities during pre-service education period. Schools are the institutions where teaching is performed; however, they are also social systems with unique circumstances and differences. School administrators, other teachers, and parents, all of which constitute the group of stakeholders, expect novice teachers to play certain roles within the system other than teaching (Richards, Templin, \& Gaudreault, 2013). In case of pre-service teachers who lack the competencies to perform these roles being well aware of these expectations leads to an increase in their reality shock expectations.

In the present study, in line with the third research question, it was also examined whether pre-service teachers' reality shock expectations differed significantly in relation to gender when their occupational concerns were controlled. The ANCOVA results concerning this aim implied that expectations of reality shock were experienced at the same level by both genders. Having conducted a similar study, Kim and Cho (2014) reported that male pre-service experienced reality shock expectations more than female pre-service teachers, which would be an indicator of the probability that teaching is becoming a profession for females. However, occupational concern levels of the participants in the sampling were not controlled statistically in that study. Though previous research has reported that female 
and male pre-service teachers had similar levels of occupational concerns (Atmaca, 2013; Dilmaç, 2010; Temiz, 2011), a wide range of studies point out that Turkish female pre-service teachers experience higher levels of concerns than males (e.g., Çakmak \& Hevedanlı, 2005; Kapıkıran, 2006; Taşğın, 2006; Tümerdem, 2007). In Turkey, females are exposed to more pressure in their families and collateral kinship in accordance with the social and cultural values, causing them to have lower levels of self-confidence and self-respect, which leads them to perceive even a simple thing as a source of concern. However, as the current study was conducted in Ankara -the capital city of Turkey- and Samsun -one of the big cities- the facilities of these metropolitan cities and university life may have influenced their perceptions and expectations by enabling them to encounter diverse experiences.

We also concluded that when the occupational concern levels of the participants were standardized, the reality shock expectation levels did not differ in relation to accommodation unit, and socio-economic status. The accommodation units where students were born and spent most of their lifetimes have unique cultures and lifestyles. Studies have shown that those who were born and grown up in rural areas have relatively less access to educational opportunities (Qian \& Smyth, 2005; Shan \& Stifel, 2003). Findings indicated that reality shock expectation levels did not differ even though they lived in different accommodation units. On the basis of this finding, the researchers believe that reality shock expectation of pre-service teachers is not related to their backgrounds, but it is related to their future concerns. Further, reality shock expectation of the participants did not dif- fer statistically according to their socio-economic status. This is consistent with previous findings (Dursun \& Karagün, 2012). Pre-service teachers who make different amounts of expenditures monthly did not differ in relation to their reality shock expectations. This might be linked to the fact that majority of the students in teacher education programs are from lower and middle income families in Turkey (Köksalan, İlter, \& Görmez, 2010). Therefore, although there were differences concerning socio-economic status among pre-service teachers, it can be considered that their reality shock expectations did not differ statistically, as they have similar socio-economic levels.

The research revealed that reality shock expectations of the participants differed statistically regarding their teacher education programs when their occupational concern levels were controlled. The ANCOVA results indicated that teacher education program was a significant predictor of reality shock expectation. This finding contradicts with Kim and Cho's (2014) findings that reality shock expectations of the participants did not differ in relation to teacher education program variable. The results from Turkish sampling showed that pre-service teachers studying elementary education had higher levels of reality shock expectations than those studying special education, whereas no statistically significant difference was detected among other participants studying foreign language education, Turkish education, science and math education, psychological guidance and counseling and computer and technology education programs. One of the underlying factors of the relatively higher reality shock expectations of pre-service teachers studying elementary education might be the limited employment 
possibilities in Turkey due to higher numbers of graduates. Additionally, even though elementary education graduates succeed in getting a position, first they are appointed to the schools in rural and less developed areas of the country. However, pre-service teachers are not trained to cope with potential challenges they may encounter in rural and less developed areas of the country. Further, as participants enrolled in the aforementioned teacher education programs have lower levels of probability to be appointed to a public school after graduation, compared to elementary education and special education programs' graduates, they may feel less or similar levels of reality shock expectation since they do not expect themselves to be employed in public schools.

The study lastly examined whether occupational concern level of pre-service teachers was a significant predictor of their reality shock expectation in line with the last research question. In this respect a multiple regression analysis was conducted, and the results demonstrated that occupational concern explained $11 \%$ of the variance in reality shock expectation. Furthermore, it was revealed that concern about appointment, social and economic concerns, and concern about students/communication were significant predictors of reality shock expectation. Findings obtained in the current study indicated that occupational concern is a triggering factor for reality shock expectation. Accordingly, uncertainty of the future is reported to raise concerns in individuals (Cüceloğlu, 1996). A study conducted in Turkey portrayed that pre-service teachers had concerns about getting appointed after graduation (Kaya \& Büyükkasap, 2005). Therefore, the findings obtained in this study are consistent with related literature.

\section{Conclusion and Recommendations}

In the present study, the relationship between reality shock expectation and occupational concern of pre-service teachers studying in Turkish universities was examined. Results of the analyses pointed out that reality shock expectation of the participants was high, and their occupational concern level was relatively low. Reality shock expectation of the participants was found not to differ in relation to their gender, accommodation unit, and socio-economic status, when their occupational concern level was standardized. Yet, ANCOVA results indicated that reality shock expectation of the participants differed in relation to their teacher education programs. Further, there is a low, yet positive and significant relationship between reality shock expectation and occupational concerns of pre-service teachers. Occupational concern was found to be a significant predictor of reality shock expectation of the participants. Participants had concern about appointment, students/communication and social and economic concerns most. This finding could be generalized to the result that such occupational concerns are also triggering factors for reality shock expectation.

The current study was conducted in two state universities in Turkey. Further studies may compare the opinions of pre-service teachers on reality shock expectation studying in state, foundation, and private universities. Further research may examine the relationship of reality shock expectation and variables other than occupational concerns. In the current study, a quantitative correlational model was employed to investigate the relationships among three attitudinal constructs. Yet, qualitative studies, providing in- 
depth-analysis for the opinions of the participants are considered to make significant contribution to related literature, as well. Finally, future studies on reality shock expectation may be recommended to be conducted among pre-service teachers from different countries with varied socio-economic status.

Received September 22, 2015

\section{References}

Adıgüzelli, Y. (2015). Examination of occupational concern of pre-service teachers based on various variables in Turkey. Educational Research and Reviews, 10(4), 397-402. doi: 10.5897/ERR2015. 2075

Alasheev, S. I., \& Bykov, S. V. (2002). Teachers' state of anxiety. Russian Education and Society, 45(12), 62-72.

Al-Awidi, H. M., \& Alghazo, I. M. (2012). The effect of student teaching experience on preservice elementary teachers' self-efficacy beliefs for technology integration in the UAE. $E d u$ cational Technology Research and Development, 60(5), 923-941.

Atmaca, H. (2013). The professional concerns of teachers candidates who enrolled in English, French and German teaching departments. Turkish Studies, 8, 67-76.

Beck, C. T. (1993). Nursing students initial clinical experience: A phenomenological study. International Journal of Nursing Studies, 30(6), 489 497.

Betts, R. T. (2006). Lived experiences of long-term supply beginning teachers in New Brunswik: A hermeneutic phenomenological approach (Unpublished doctoral dissertation). The University of New Brunswik, Brunswik.

Bozdam, A., \& Taşğın, Ö. (2011). Öğretmen adaylarının mesleki kaygı düzeylerinin bazı değişkenler açısından incelenmesi [An investigation of pre-service teachers' occupational concern levels in relation to some variables]. Selçuk Üniversitesi Beden Eğitimi ve Spor Bilimi Dergisi, 13(1), 44-53.

Cabı, E., \& Yalçınalp, S. (2013). Öğretmen adaylarına yönelik mesleki kaygı ölçeği (MKÖ) Geçerlik ve güvenirlik çalıșması [Occupational Concerns Scale (OCS) for pre-service teachers:
A validity and reliability study]. Hacettepe Üniversitesi Eğitim Fakültesi Dergisi, 44, 85-96. Cabı, E., \& Yalçınalp S. (2009). Öğretmen adaylarının mesleki ve eğitim teknolojilerini kullanma kaygı düzeylerine yönelik görüşleri [Preservice teachers' opinions on their occupational concerns and concern of using educational technologies]. IV. International Educational Technology Conference, Hacettepe Üniversitesi.

Caires, S., Almeida, L. S., \& Martins, C. (2010). The socioemotional experiences of student teachers during practicum: A case of reality shock? The Journal of Educational Research, 103, 17-27.

Chong, S., Low, E. L., \& Goh, K. C. (2011). Emerging professional teacher identity of pre-service teachers. Australian Journal of Teacher Education, 36(8), 50-64.

Chubbuck, S. M. (2008). A novice teacher's beliefs about socially just teaching: Dialogue of many voices. The New Educator, 4(4), 309-329.

Chubbuck, S. M., Clift, R. T., Allard, J., \& Quinlan, J. (2001). Playing it safe as a novice teacher: Implications for programs for new teachers. Journal of Teacher Education, 52(5), 365-376.

Cüceloğlu, D. (1996). Insan ve davranışı: Psikolojinin temel kavramlarl [Human and behavior: Basic concepts in psychology]. İstanbul: Remzi Kitabevi.

Çakmak, Ö., \& Hevedanlı, M. (2005). Eğitim ve fen-edebiyat fakülteleri biyoloji bölümü öğrencilerinin kaygı düzeylerinin çeşitli değişkenler açısından incelenmesi [Investigating the concern levels of education and letters faculties' pre-service biology teachers in relation to various variables]. Elektronik Sosyal Bilimler Dergisi, 4(14), 115-127.

Çubukçu, Z., \& Dönmez, A. (2011). The examination of the professional anxiety levels of teacher candidates. Journal of Theory and Practice in Education, 7(1), 3-25.

Darling-Hammond, L. (2000). Solving the dilemmas of teacher supply, demand and standards: How we can ensure a competent, caring, and qualified teacher for every child. National Commission on Teaching \& America's Future Report, New York, NY.

Davison, G. C. (2008). Abnormal Psychology. Toronto: Veronica Visentin.

Dean, R. A., \& Wanous, J. P. (1983). Reality shock and commitment: A study of new employees' expectations. Paper presented at the Annual Convention of the American Psychological Association, Anaheim, CA, August 26-30. 
Dean, R. A., Ferris, K. R., \& Konstants, C. (1988). Occupational reality shock and organizational commitment-evidence from the accounting profession. Accounting Organization and Society, 13(3), 235-250.

Department of Education, Science and Training (DEST) (2003). Australia's Teachers: Australia's future: Advancing innovation, science, technology and mathematics. Canberra: DEST.

Depolo, M., Fraccaroli, F., \& Sarchielli, G. (1992). Mismatches between expectation and reality in the work socialization process. Traveil Humain, 57(2), 131-143.

Dhar, R. L. (2012). Reality shock: Experiences of Indian information technology (IT) professionals. Work, 46, 251-262.

Dilmaç, O. (2010). Görsel sanatlar öğretmeni adaylarının kaygı düzeylerinin çeşitli değişkenler açısından incelenmesi [Investigating the concern levels of visual arts pre-service teachers in relation to various variables]. Atatürk Üniversitesi Görsel Sanatlar Enstitüsü Dergisi, 24, 49-65.

Duchscher, J. E. B. (2009). Transition shock: The initial stage of role adaptation for newly graduated registered nurses. Journal of Advance Nursing, 65(5), 1103-1113.

Dursun, S., \& Karagün, E. (2012). Öğretmen adaylarının mesleki kaygı düzeylerinin incelenmesi: Kocaeli Üniversitesi Beden Eğitimi ve Spor Yüksek Okulu son sınıf öğrencileri üzerine bir araştırma [An investigation of pre-service teachers' anxiety levels: A study on Kocaeli University School of Physical Education and Sports]. Kocaeli Üniversitesi Sosyal Bilimler Dergisi, 24. 93-112.

Dyess, S. M., \& Sherman, R. O. (2009). The first year of practice: New graduate nurses' transition and learning needs. The Journal of Continuing Education in Nursing, 40(9), 403-410.

Ekici, G., \& Kurt, H. (2012). Biyoloji öğretmen adaylarının kamu personeli seçme sınavına (KPSS) yönelik kaygı ve saldırganlık düzeylerinin farklı değişkenlere göre incelenmesi [Concern and aggression levels of pre-service biology teachers towards Public Personnel Selection Examination]. Ĕgitim ve Öğretim Araştırmaları Dergisi, 1(4), 294-308.

Ewing, R. A., \& Smith, D. L. (2003). Retaining quality beginning teachers in the profession. English Teaching: Practice \& Critique, 2(1), 15 32 .

Farrell, T. S. C. (2006). The first year of language teaching: Imposing order. System, 34, 211-221.
Fuller, F. F. (1969). Concerns of teachers: A developmental conceptualization. American Education Research Journal, 6, 207-226.

Fuller, F. F. (1975). Concerns of teachers: A developmental conceptualization. In M. Mohan \& R. E. Hull (Eds.). Teaching effectiveness (pp. 176). New Jersey: Educational Technology Publications.

Gibbs, C. (2002). Effective teaching: Exercising selfefficacy and thought control of action. Paper presented at the Annual Conference of the British Educational Research Association, University of Exeter, England, 12-14 September 2002.

Goddard, R., \& Goddard, M. (2006). Beginning teacher burnout in Queensland schools: Association with serious intention to leave. The Australian Educational Researcher, 33(2), 61-75.

Haggarty, L., \& Postlethwaite, K. (2009). An exploration of changes in thinking in the transition from student teacher to newly qualified teacher. Research Papers in Education, 27(2), 241-262.

Hagger, H., Mutton, T., \& Burn, K. (2011). Surprising but not shocking: The reality of the first year of teaching. Cambridge Journal of Education, 41(4), 387-405.

Harmon, H. L. (2001). Attracting and retaining teachers in rural areas. Paper presented at the Annual Meeting of the American Association of Colleges for Teacher Education, Dallas, Texas, March 1-4, 2001.

Hobson, A. J., \& Ashby, P. (2012). Reality aftershock and how to avert it: Second-year teachers' experiences of support for their professional development. Cambridge Journal of Education, 42(2), 177-196.

Horn, E. (1966). Teachers who remain in the classroom: An interview study of persisting teachers. New York: City University of New York. Division of Teacher Education.

Ingersoll, R. M., \& Smith, T. M. (2004). Do teacher induction and mentoring matter? NASSP Bulletin, 88, 28-40.

Kapıkıran, N. A. (2006). Başarı Kaygısı Ölçeği'nin geçerliği ve güvenirliği [The validity and reliability study of Achievement Anxiety Testing]. Pamukkale Üniversitesi Eğitim Fakültesi Dergisi, 19, $1-6$.

Karamustafaoğlu, O., \& Özmen, H. (2004). Toplumumuzda ve ögretmen adayları arasında ögretmenlik mesleğine verilen değer üzerine bir araştırma [A study on the value of teaching profession from the eyes of the society and pre- 
service teachers]. Değerler Ë̆itimi Dergisi, 2(6), 35-49.

Kavcar, C. (2002). Cumhuriyet döneminde dal öğretmeni yetiștirme [Training branch teachers in Republic period]. Ankara Üniversitesi Eğitim Bilimleri Fakültesi Dergisi, 35(1), 1-14.

Kaya, A., \& Büyükkasap, E. (2005). Fizik öğretmenliği programı öğrencilerinin profilleri, öğretmenlik mesleğine yönelik tutum ve endișeleri: Erzurum örneği [The profile of physics education students, their attitudes and concerns about teaching profession: Sample of Erzurum Province]. Kastamonu Eğitim Dergisi, 13(2), 367-380.

Kim, H., \& Cho, Y. (2014). Pre-service teachers' motivation, sense of teaching efficacy, and expectation of reality shock. Asia-Pacific Journal of Teacher Education, 42(1), 67-81.

Kiraz, E., Demir, C., Aksu, M., Daloğlu, A., \& Yıldırım, S. (2010). Investigating educational views of prospective teachers according to different variables. Elementary Education Online, 9(2), 526-540

Korkmaz, İ., Saban, A., \& Akbaşl1, S. (2004). Göreve yeni başlayan sınıf öğretmenlerinin karşılaştıklar güçlükler [The difficulties that novice teachers experience]. Kuram ve Uygulamada Ĕgitim Yönetimi Dergisi, 38, 266-277.

Köksalan, B., İlter, H., \& Görmez, E. (2010). Sınıf öğretmeni adaylarının sosyo-kültürel özellikleri ve lisansüstü eğitim isteklilikleri üzerine bir çalışma (Fırat, Erzincan ve İnönü Üniversitesi Sınıf öğretmenliği Anabilim dalı örneği) [A study on pre-service primary education teachers' sociocultural characteristics and willingness on graduate education (Sample of Firat, Erzincan and İnönü Universities Primary Education Programs)]. Ahi Evran Üniversitesi Eğitim Fakültesi Dergisi, 11(3), 277-299.

Kramer, M. (1974). Reality shock; why nurses leave nursing. Saint Louis: C.V. Mosby Co.

Külekçi, G. (2011). A study on pre-service English teachers' self-efficacy beliefs depending on some variables. International Online Journal of Educational Sciences, 3(1), 245-260.

Macdonald, D. (1999). Teacher attrition: A review of literature. Teaching and Teacher Education, 15(8), 835-848.

Mafora, P. (2013). Managing teacher retention in a rural school district in South Africa. The Australian Educational Researcher, 40(2), 227-240.

MEB (2010). Milli Eğitim Bakanlığı Öğretmenlerin Atama ve Yer Değiştirme Yönetmeliği [The Min- istry of National Education's Regulations on Teachers' Appointment and Replacement]. RG: 06.05.2010/27573.

Öztürk, M., \& Yıldırım, A. (2013). Adaptation challenges of novice teachers. Hacettepe Üniversitesi Ĕ̈itim Fakültesi Dergisi, 28(1), 294-307.

Pendergast, D., Garvis, S., \& Keogh, J. (2011). Pre-service student-teacher self-efficacy beliefs: An insight into the making of teachers. Australian Journal of Teacher Education, 36(12), 4657

Qian, X., \& Smyth, R. (2005). Measuring regional inequality of education in China: Widening coastinland gap or widening rural-urban gap? Australia ABERU Discussion Paper 12.

Richards, K. A., Templin, T. J., \& Gaudreault, K. L. (2013). Understanding the realities of school life: Recomendations for the preparation of physical education teachers. Quest, 65, 442-457.

Rowan, B., Correnti, R., \& Miller, R. (2002). What large-scale survey research tells us about teacher effects on student achievement: Insight from the prospects study of elementary schools. Teachers College Record, 104(8), 1525-1567.

Rousseau, H. J. (1968). The impact of educational theory on teachers. British Journal of Educational Studies, 16(1), 60-71.

Saban, A., Korkmaz, İ., \& Akbașl1, S. (2004). The professional concerns of pre-service teachers. Eurasian Journal of Educational Research, 17, 198-208.

Sammephet, B., \& Wanphet, P. (2013). Pre-service teachers' anxiety and anxiety management during the first encounter with students in EFL classroom. Journal of Education and Practice, 4(2), 78-87.

Saracaloğlu, A. S., Kumral, O., \& Kanmaz, A. (2009). Ortaöğretim sosyal alanlar öğretmenliği tezsiz yüksek lisans öğrencilerinin öğretmenlik mesleğine yönelik yeterlikleri, kaygıları ve akademik güdülenme düzeyleri [The competencies, concerns and academic motivation of secondary social sciences education non-thesis program's students]. Yüzüncü Yll Üniversitesi Ĕ̆itim Fakültesi Dergisi, 6(2), 38-54.

Senom, F., Zakaria, A. R., \& Shah, S. S. A. (2013). Novice teachers' challenges and survival: Where do Malaysian ESL teachers stand? American Journal of Educational Research, 1(4), 119125.

Shan, D. E., \& Stifel, D. C. (2003). Progress toward the millennium development goals in Africa. World Development, 31(1), 23-52. 
Stacey, G., \& Hardy, P. (2011). Challenging the shock of reality through digital storytelling. Nurse Education in Practice, 11, 159-164.

Stokking, K., Leenders, F., de Jong, J., \& van Tartwijk, J. (2003). From student to teacher: Reducing practice shock and early dropout in teacher education. European Journal of Teacher Education, 26(3), 329-350.

Taşğın, Ö. (2006). Beden Eğitimi ve Spor Yüksekokulu'nda okuyan öğretmen adaylarının mesleki kaygı düzeylerinin bazı değişkenler açısından incelenmesi [Investigating the occupational concern levels of pre-service physical education and sports teachers in relation to some variables]. Kastamonu Eğitim Dergisi, 14(2), 679-686.

Temiz, E. (2011). Güzel sanatlar eğitimi bölümü öğretmen adaylarının mesleki kaygı düzeylerinin cinsiyet ve alan değişkenleri açısından incelenmesi [Investigating the occupational concern levels of pre-service visual arts teachers in relation to their gender and branches]. E-Journal of New World Sciences Academy, 6(2), 303310 .

Trent, J. (2012). Becoming a teacher: The identity construction experiences of beginning English language teachers in Hong Kong. The Australian Educational Researcher, 39(3), 363-383.

Tümerdem, R. (2007). Dicle Üniversitesi Eğitim Fakültesi ve Fen-Edebiyat Fakültesi kimya son sınıf ögrencilerinin kaygılarını etkileyen etmenler [The factors influencing the anxiety levels of senior year chemistry students attending Dicle University Faculty of Education and Faculty of Arts and Letters]. Elektronik Sosyal Bilimler Dergisi, 6(20), 32-45.

Ünald1, Ü. E., \& Alaz, A. (2008). Coğrafya öğretmenliğinde okuyan öğretmen adaylarının mesleki kaygı düzeylerinin bazı değişkenler açısından incelenmesi [An investigation of preservice geography teachers' occupational concern levels in relation to some variables]. Selçuk Üniversitesi Ahmet Keleşoğlu Eğitim Fakültesi Dergisi, 26, 1-13.

Veenman, S. (1984). Perceived problems of beginning teachers. Review of Educational Research, $54,143-17$.

Wagner, L. A. (2008). Occupational stress and coping resources of $\mathrm{K}-12$ probationary teachers (Unpublished doctoral dissertation). The University of Denver, Colorado.

Weinstein, C. S. (1988). Preservice teachers' expectations about the first year of teaching. Teaching \& Teacher Education, 4(1), 31-40.

Wright, S. P., Horn, S. P., \& Sanders, W. L. (1997). Teacher and classroom context effects on student achievement: Implications for teacher evaluation. Journal of Personnel Evaluation in Education, 11, 57-67.

Yeşil, R. (2009). Sosyal bilgiler aday öğretmenlerinin sınıf içi öğretim yeterlikleri: Kırşehir örneği [Inclass teaching qualifications of pre-service social sciences teachers]. Türk Ĕgitim Bilimleri Dergisi, 7(1), 23-48. 